\title{
Oligosarcus perdido (Characiformes, Characidae), a new species of freshwater fish from Serra da Bodoquena, upper Rio Paraguai basin, Brazil
}

\author{
ALEXANDRE C. RIBEIRO ${ }^{1,2}$, MARCEL R. CAVALLARO ${ }^{2,3} \&$ OTÁVIO FROEHLICH ${ }^{4}$ \\ ${ }^{1}$ Instituto de Biociências, Universidade Estadual Paulista Júlio de Mesquita Filho-UNESP. Distrito de Rubião Júnior s/n. 18618-000, \\ Botucatu, SP, Brazil.E-mail: acribeiro@click21.com.br \\ ${ }^{2}$ LIRP - Laboratório de Ictiologia de Ribeirão Preto, Departamento de Biologia, FFCLRP, Universidade de São Paulo, Av. Bandei- \\ rantes, 3900, 14040-901, Ribeirão Preto-SP, Brazil (mailing address). \\ ${ }^{3}$ Programa de Pós-Graduação em Biologia Comparada (Doutoramento). Universidade de São Paulo (USP), Depto. de Biologia da \\ FFCLRP, Laboratório de Ictiologia de Ribeirão Preto (LIRP), Avenida dos Bandeirantes, 3900, Ribeirão Preto-SP, 14040-901, Brazil. \\ E-mail: mrcavallaro@gmail.com \\ ${ }^{4}$ Universidade Federal de Mato Grosso do Sul, Departamento de Biologia / CCBS, Caixa Postal 549, 79070-900, Campo Grande, MS, \\ Brazil.E-mail: otavio@nin.ufms.br
}

\begin{abstract}
Oligosarcus perdido, a new species of freshwater fish from Serra da Bodoquena, upper Rio Paraguai basin, Brazil, is described. The new species is distinguished from congeners by the number of lateral-line scales, number of scales around the caudal peduncle, and osteological characters. The osteology of this new species is also documented by stereomicroscopic photography of cleared and stained specimens. Ecological notes based on direct observation by scuba diving in the field are also provided.
\end{abstract}

Key words: Taxonomy, freshwater fishes, Neotropical region

\section{Introduction}

The genus Oligosarcus consists of 16 previously described species (Menezes, 1969a; Menezes, 1987; Miquelarena \& Protogino, 1996), distributed throughout most of the main hydrographic systems of cisAndean South America below $14^{\circ}$ of latitude (Menezes, 1988). This wide distributional range includes the Bolivian and Argentinean Andean highlands, the Brazilian crystalline shield, and the Atlantic slope drainages of eastern and southern South America (Menezes, 1988). Species of Oligosarcus are typically small-to medium sized predators on arthropods and other fishes, inhabiting mainly smaller tributaries of the main river basins (Menezes, 1969b; Aranha et. al, 1998; Casatti, 2003; Hermes-Silva et al., 2004).

Menezes (1987) provided a comprehensive review of the previous known species and described three new ones. The latest addition to the genus was made by Miquelarena \& Protogino (1996) in describing Oligosarcus menezesi. No intraspecific phylogenetic information on this genus has been already provided; however, the presence of tricuspid teeth along most of ectopterygoid length, a unique feature among a set of genera presently assigned as incertae sedis in Characidae (Lima et al, 2003), suggests that the genus consists of a monophyletic group. The phylogenetic relationships and biogeography of Oligosarcus are currently under study by one of the authors (ACR).

Recent collecting efforts in the Serra da Bodoquena, a calcareous plateau located at the southern margin of the Pantanal wetland, upper Paraguai basin, Brazil, yielded a new species of Oligosarcus, which is described herein. 